\title{
High-Level Expression of Palmitoylated MPP1 Recombinant Protein in Mammalian Cells
}

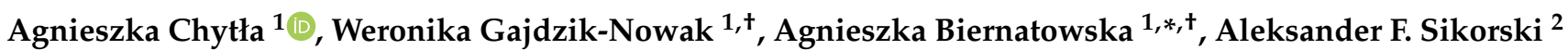 \\ and Aleksander Czogalla $1, *$ (D)
}

1 Department of Cytobiochemistry, Faculty of Biotechnology, University of Wroclaw, 50-383 Wroclaw, Poland; agnieszka.chytla@uwr.edu.pl (A.C.); weronika.gajdzik@uwr.edu.pl (W.G.-N.)

2 Research and Development Center, Regional Specialist Hospital, Kamieńskiego 73a, 51-154 Wroclaw, Poland; aleksander.sikorski@wssk.wroc.pl

* Correspondence: agnieszka.biernatowska@uwr.edu.pl (A.B.); aleksander.czogalla@uwr.edu.pl (A.C.); Tel.: +48-7-1375-417 (A.B.); +48-7-1375-6356 (A.C.)

+ These authors contribute equally.

check for updates

Citation: Chytła, A.; Gajdzik-Nowak, W.; Biernatowska, A.; Sikorski, A.F.; Czogalla, A. High-Level Expression of Palmitoylated MPP1 Recombinant Protein in Mammalian Cells.

Membranes 2021, 11, 715. https:// doi.org/10.3390/membranes11090715

Academic Editor: Mihaela Delcea

Received: 20 August 2021

Accepted: 10 September 2021

Published: 17 September 2021

Publisher's Note: MDPI stays neutral with regard to jurisdictional claims in published maps and institutional affiliations.

Copyright: (c) 2021 by the authors. Licensee MDPI, Basel, Switzerland. This article is an open access article distributed under the terms and conditions of the Creative Commons Attribution (CC BY) license (https:// creativecommons.org/licenses/by/ $4.0 /)$.

\begin{abstract}
Our recent studies have pointed to an important role of the MAGUK family member, MPP1, as a crucial molecule interacting with flotillins and involved in the lateral organization of the erythroid plasma membrane. The palmitoylation of MPP1 seems to be an important element in this process; however, studies on the direct effect of palmitoylation on protein-protein or proteinmembrane interactions in vitro are still challenging due to the difficulties in obtaining functional post-translationally modified recombinant proteins and the lack of comprehensive protocols for the purification of palmitoylated proteins. In this work, we present an optimized approach for the highyield overexpression and purification of palmitoylated recombinant MPP1 protein in mammalian HEK-293F cells. The presented approach facilitates further studies on the molecular mechanism of lateral membrane organization and the functional impact of the palmitoylation of MPP1, which could also be carried out for other palmitoylated proteins.
\end{abstract}

Keywords: MPP1; palmitoylation; membrane rafts; HEK-293F; transfection; purification; Acyl-RAC

\section{Introduction}

Membrane-associated guanylate kinases (MAGUKs) are widely expressed proteins in all types of eukaryotic cells [1]. This well-conserved group of scaffolding proteins includes several subfamilies that are involved in multiple cellular processes, such as cell polarity, cell signalling, and cell adhesion [2,3]. One of these subfamilies is named the membrane palmitoylated proteins (MPPs). MPPs are ubiquitously expressed, membrane-associated, palmitoylated proteins found at the cytosolic leaflet of the plasma membrane (PM) [4]. Similar to other MAGUKs, they contain a highly conserved core of postsynaptic density protein 95/disc large/zonula occludens-1 (PDZ) domain, an Src homology 3 (SH3) domain, and a catalytically inactive guanylate kinase (GUK) domain. Another characteristic domain shared within some members of the MPP family is the D5 domain, also known as HOOK [4,5]. One of the most thoroughly examined members of this group, MPP1, was first described in red blood cells (RBCs) and is primarily known for its role in maintaining the proper shape of erythrocytes by participating in the formation of a ternary complex together with the 4.1R protein and glycophorin C [6-8]. Importantly, our previous studies demonstrated the key role of MPP1 in the lateral organization of the erythroid cell membrane [9-12]. Experiments performed on the human erythroleukemia cell line (HEL), which are erythrocyte progenitor cells, showed that silencing MPP1 expression or the inhibition of its palmitoylation significantly reduced the order parameters of both PM or PM-derived vesicles in comparison to control cells [9,13]. Moreover, a reduction in MAP kinase signalling pathway activation via raft-dependent RTK receptors and their downstream 
signalling pathways was also observed [11]. Thus, these studies emphasized that MPP1 acts as a specific "organizer" of the lateral membrane and influences the formation of functional membrane rafts at the PM of erythroid cells. Although the relevance of membrane rafts, defined as heterogeneous, dynamic protein-lipid nanodomains in the spatio-temporal compartmentalization of membrane components, is well characterized $[14,15]$ the physiological factors driving their organization are still poorly characterized. On the other hand, it has become evident that the lateral organization of biological membranes into specified domains depends on the cooperative interaction/clustering of protein and lipids (for a review, see [15]). Specific endogenous membrane-organizers have therefore been intensively researched. In this particular context, to understand the MPP1-driven membrane raft formation, our further studies of the MPP1 interactome have led to the identification of novel protein partners of MPP1, the raft protein markers flotillin 1 and flotillin 2 [10]. Flotillins represent the major structural scaffolding proteins in erythroid raft domains [16]. Due to their oligomeric nature, flotillins serve as assembly sites enabling the association of different molecules, thus actively contributing to numerous cellular processes (e.g., endocytosis, signalling) in the PM [17-20]. Most recently, using a surface plasmon resonance-based approach and recombinant proteins overexpressed in bacterial cells, we determined the kinetic parameters for the MPP1-flotillin 1/flotillin 2 interactions and showed that these proteins form high-affinity complexes in vitro. Moreover, using molecular dynamics simulations and a series of MPP1-truncated mutants, we identified a flotillin binding site within the MPP1 D5 domain [21]. Based on our findings and models presented by others [22], we hypothesize that MPP1 triggers the clustering of flotillins-based assemblies into functional membrane raft domains in the PM $[10,21]$. Such a concept also fits the model ascribing the dominant role of scaffolding proteins in capturing rafts-associated elements [23]. However, to obtain a full picture of the mechanism, one important issue related to MPP1 palmitoylation needs to be further addressed. Palmitoylation is an important lipid modification that relies on the attachment of palmitate to internal cysteine residues via a thioester linkage [24]. In the case of MAGUK proteins, palmitoylation is fundamental, enabling the recruitment and association of other molecules and the formation of multi-component complexes at the cytosolic leaflet of the PM. This has been well documented in neurons, where the palmitoylation of the PSD-95 (postsynaptic density 95) protein determines the clustering of AMPA ( $\alpha$-amino-3-hydroxy-5-methylisoxazole-4-propionic acid) receptors and, thus, provides proper synaptic trafficking and neuron activity [25-27]. On the other hand, the palmitoylation of PSD-95 was found to be significant for the stabilization of cholesterol and sphingomyelin-enriched domains during neuronal development [28].

MPP1 is the major palmitoylated protein in RBC membranes [6] and the inhibition of its palmitoylation was shown to correlate with changes in lateral PM organization in erythroid cells [9]. To study the molecular mechanisms of this issue, in vitro studies on the direct effect of palmitoylated proteins using model membranes are required but also challenging. While it is possible to obtain a high yield of recombinant MPP1 protein from Escherichia coli cells $[5,10,21,29]$, the bacterial system cannot be used to overexpress the protein with crucial post-translational modifications (PTM), such as palmitoylation, because it lacks palmitoyl acyltransferases or related enzymes. On the other hand, overexpression in mammalian systems offers molecular chaperones and co-factors that allow for the production of correctly folded proteins with the desired PTMs, which are important for their functionality and full activity $[30,31]$. So far, most reports describe the purification of glycosylated proteins [32-34]; however, a detailed protocol describing the step-by-step overexpression and purification of palmitoylated recombinant proteins is currently missing.

In this study, we optimized the transient expression of the MPP1 protein in HEK FreeStyle ${ }^{\mathrm{TM}}$ 293-F cells (HEK-293F). To the best of our knowledge, this is the first work describing the purification of "in cellula" palmitoylated protein overexpressed in the mammalian system. The presented study not only facilitates further research on the functional impact of palmitoylated MPP1 on PM organization in vitro but may also serve 
as a primer for the overexpression and purification of other recombinant palmitoylated peripheral membrane proteins.

\section{Materials and Methods}

\subsection{Plasmid/DNA}

An expression vector carrying a sequence encoding fused protein, mEGFP-MPP1 (Figure S1), was prepared by cloning the MPP1 sequence (NCBI Reference Sequence: NM_002436.3) into the mEGFP-HRas plasmid (Addgene Plasmid \#18662) using XhoI and NotI restriction sites (Table $\mathrm{S} 1$ ).

A pcDNA3.1 Hygro-ACP_His-tag_MPP1_TAP-tag expression vector was constructed and synthesized commercially (GenScript). The MPP1 sequence was flagged by an ACP-tag (Acyl Carrier Protein) and a His-tag at the N-terminus and a TAP-tag at the C-terminus. A Tobacco Etch Virus (TEV) and an enterokinase recognition site (EK) precede the MPP1 sequence, and a $3 \mathrm{C}$ protease recognition site precedes the TAP-tag. The ACP-tag sequence plus the sequence recognized by the TEV protease were deleted using site-directed mutagenesis $\left(\mathrm{Q} 5{ }^{\circledR}\right.$ Kit, NEB) (Table S1). The resulting construct containing a His-tag and TAP-tag only was used in further work (Figure S1a,b).

\subsection{Cell Culture and Transfection}

The FreeStyle ${ }^{\mathrm{TM}}$ 293-F cells (HEK-293F, Thermo Fisher Scientific, Waltham, MA, USA) were grown according to the manufacturer's instructions in $125 \mathrm{~mL}$ or $500 \mathrm{~mL} \mathrm{Nal}-$ gene $^{\mathrm{TM}}$ Erlenmeyer flasks with plain bottoms and vented caps (Thermo Fisher) in the FreeStyle ${ }^{\mathrm{TM}}$ medium at $37^{\circ} \mathrm{C}$ in an $8 \% \mathrm{CO}_{2}$ atmosphere with gentle shaking (130 rpm, Infors HT Minitron).

One day before the transfection, cells were sub-cultured to a density of $10^{6}$ cells $/ \mathrm{mL}$. On the day of transfection, cells were centrifuged at $200 \times g$ at RT for $5 \mathrm{~min}$, resuspended in fresh medium $\left(10 \mathrm{~mL}\right.$ for optimization experiments in $25 \mathrm{~cm}^{2} \mathrm{Nunc}^{\mathrm{TM}}$ EasYFlask ${ }^{\mathrm{TM}}$ or $500 \mathrm{~mL}$ for overexpression in $2 \mathrm{~L}$ flasks) at a density of $10^{6}$ cells $/ \mathrm{mL}$, and transfected using DNA and $25 \mathrm{kDa}$ linear polyethyleneimine (PEI, Polysciences, Warrington, PA, USA) polyplexes. Briefly, the working solutions of the DNA and working solutions of the PEI were prepared separately in sterile $150 \mathrm{mM} \mathrm{NaCl}$, then mixed and incubated at room temperature for $10 \mathrm{~min}$. After the incubation, DNA-PEI polyplexes were added to the cell culture $\left(0.5 \mu \mathrm{g}\right.$ DNA per $10^{6}$ cells). The final volume ratio of polyplexes and cell culture medium was $1 / 10$. Depending on the experiment, cells were incubated with DNA-PEI either for $17 \mathrm{~h}$ at $31^{\circ} \mathrm{C}$, or $5 \mathrm{~h}$ at $37^{\circ} \mathrm{C}$, then the cells were centrifuged at $200 \times g$, RT for $5 \mathrm{~min}$ and resuspended in the same volume of a fresh medium to remove any remaining polyplexes or free PEI, which is toxic to cells [35]. After centrifugation, cells transfected at $31{ }^{\circ} \mathrm{C}$ were returned to the incubator and cultured for an additional $48 \mathrm{~h}$. As for the cells transfected for $5 \mathrm{~h}$ at $37^{\circ} \mathrm{C}$, they were cultured for another $17 \mathrm{~h}$ at $37^{\circ} \mathrm{C}$ for regeneration, followed by incubation at $31^{\circ} \mathrm{C}$ for another $48 \mathrm{~h}$. The temperature change from $37^{\circ} \mathrm{C}$ to $31^{\circ} \mathrm{C}$ was intended to induce mild hypothermia, since it is supposed to stimulate protein overexpression in mammalian systems [36].

\subsection{Transfection Analysis}

For the optimization of the transfection yield, cells were transfected with the plasmid encoding mEGFP-MPP1, as described above. Samples containing $3 \times 10^{5}$ cells were harvested after selected time points ( $24 \mathrm{~h}, 48 \mathrm{~h}$, and $72 \mathrm{~h}$ post-transfection), centrifuged ( $5 \mathrm{~min}, 200 \times g$ ), and resuspended in $500 \mu \mathrm{L}$ phosphate buffer (PBS; Gibco, Thermo Fisher Scientific, Amarillo, TX, USA). Data acquisition and analysis was performed using a NovoCyte Flow Cytometer (excitation laser: $488 \mathrm{~nm}$, detection channel equipped with bandpass emission filter $530 / 30 \mathrm{~nm}$ ) by collecting 10,000 events for each sample. A TC10 ${ }^{\mathrm{TM}}$ Automated Cell Counter (Bio-Rad, Hercules, CA, USA) was used to determine the total cell count and cell viability via the Trypan blue dye exclusion method. 


\subsection{Purification of MPP1}

MPP1-transfected cells obtained from $2 \mathrm{~L}(4 \times 500 \mathrm{~mL})$ culture were harvested after $72 \mathrm{~h}$ post-transfection, centrifuged at $2000 \times g, 4{ }^{\circ} \mathrm{C}$ for $5 \mathrm{~min}$, and resuspended in cold $50 \mathrm{mM}$ HEPES, pH 7.4, $400 \mathrm{mM} \mathrm{NaCl}$ (RES buffer), supplemented with protease inhibitors (cOmplete ${ }^{\mathrm{TM}}$ Protease Inhibitor Cocktail (Roche, Basel, Switzerland): namely, 1 tablet per $100 \mathrm{~mL}$ of buffer; $5 \mu \mathrm{M}$ E64 (Sigma-Aldrich, St. Louis, MO, USA); $100 \mu \mathrm{g} / \mathrm{mL}$ Pefabloc ${ }^{\circledR}$ SC (Roche)). Then, the cell suspension was passed through a Microfluidizer LM20 (Microfluidics International Corporation) at 5000 PSI for three cycles. Next, the collected suspension (cell lysate) was subjected to centrifugation at $500 \times \mathrm{g}$ for $10 \mathrm{~min}$ at $4{ }^{\circ} \mathrm{C}$ to remove the nuclear fraction and cell debris (P1). After centrifugation, the supernatant (S1) fraction was incubated with $2 \%$ CHAPS for $2 \mathrm{~h}$ at $4{ }^{\circ} \mathrm{C}$. After the incubation solubilized, S1 was incubated with IgG 6 Sepharose FastFlow (GE Healthcare, Chicago, IL, USA) and pre-equilibrated with a RES buffer for $2 \mathrm{~h}$ at $4{ }^{\circ} \mathrm{C}$. After the incubation, the resin was loaded on the column and washed with wash buffers (WB) in sequence: WB $(1 \times \mathrm{PBS} p H$ 7.4; $300 \mathrm{mM} \mathrm{NaCl}, 1 \%$ CHAPS, $5 \%$ glycerol), WB + $5 \mathrm{mM}$ ATP $10 \mathrm{mM} \mathrm{MgCl}_{2}$, WB, and WB +2 mM EDTA. The final step was performed using an elution buffer (EB; $1 \times$ PBS $\mathrm{pH} 7.4,150 \mathrm{mM} \mathrm{NaCl}, 0.5 \%$ CHAPS, $10 \%$ glycerol). The recombinant MPP1 protein was cleaved off from the resin using $0.04 \mathrm{mg} / \mathrm{mL}$ GST-tagged 3C protease (MPI-CBG protein facility, Dresden, Germany) through overnight incubation at $4{ }^{\circ} \mathrm{C}$. Nine $1 \mathrm{~mL}$ fractions were collected and incubated with Glutathione-Sepharose $4 \mathrm{~B}$ beads (GE Healthcare) for $1 \mathrm{~h}$ at $4{ }^{\circ} \mathrm{C}$ to remove the $3 \mathrm{C}$ protease from the MPP1 protein solution. The final clean-up of the MPP1 was carried out using PureCube 100 INDIGO Ni-Agarose (Cube Biotech, Monheim am Rhein, Germany). Fractions with the highest absorbance at $\lambda=280 \mathrm{~nm}$ were collected and either directly dialyzed for further experiments or snap-frozen in liquid nitrogen and stored at $-80^{\circ} \mathrm{C}$.

\subsection{Detection of S-Palmitoylation}

S-palmitoylation of the recombinant MPP1 protein was identified by the acyl-resin assisted capture (Acyl-RAC) method using a CAPTUREome ${ }^{\mathrm{TM}}$ S-Palmitoylated Protein Kit (Badrilla, K010-310; Leeds, UK). For the experiment, 2 mg of total protein from MPP1transfected cell lysates and $100 \mu \mathrm{g}$ of purified MPP1 recombinant protein were incubated in a blocking buffer and then incubated at $40{ }^{\circ} \mathrm{C}$ for $4 \mathrm{~h}$. Further steps of the procedure were carried out according to the manufacturer's protocol. Finally, the obtained samples, which contained palmitoylated proteins only, were subjected to SDS-PAGE separation and Western blot analysis using specific antibodies.

\subsection{SDS-PAGE and Western Blot}

The purity of the recombinant MPP1 protein was checked using SDS-PAGE and Western blot analysis or Coomassie staining. Proteins were separated on 10\% Tris-Glycine SDSPAGE gel and electrotransferred on a nitrocellulose membrane (Amersham ${ }^{\mathrm{TM}}$ Protran ${ }^{\circledR}$ ) or fixed in 50\% methanol. The membrane was blocked with 5\% skim milk in TBS-T (20 mM Tris, pH 7.4; $150 \mathrm{mM} \mathrm{NaCl}, 0.05 \%$ Tween-20) overnight at $4{ }^{\circ} \mathrm{C}$, then incubated with primary antibodies (Anti-His-tag Antibody (AD1.1.10) or Anti-GAPDH Antibody (6C5), Santa Cruz Biotechnology, Dallas, TX, USA) in TBS-T overnight at $4{ }^{\circ} \mathrm{C}$ with secondary antibodies conjugated with HRP (Peroxidase AffiniPure Goat Anti-Mouse IgG $(\mathrm{H}+\mathrm{L}$ ), Jackson Immuno Research) in TBS-T for $1 \mathrm{~h}$ at room temperature. Between each incubation step, membranes were washed with TBS-T. The blots were developed with Radiance ECL (Azure Biosystems, Dublin, CA, USA) and imaged with the Azure image system (Azure 600; Azure Biosystems). The methanol-fixed gels were stained with Coomassie Brilliant Blue G-250, then washed with distilled water and imaged with the Azure image system.

\subsection{Circular Dichroism (CD) Spectroscopy}

Purified recombinant MPP1 was dialyzed against an SLB buffer (10 mM HEPES pH 7.4, $150 \mathrm{mM} \mathrm{NaCl}$ ). Measurements were carried out with a J-1500 (JASCO) spectropolarimeter 
using a $1 \mathrm{~mm}$ path length cell in a temperature range between $10{ }^{\circ} \mathrm{C}$ and $70{ }^{\circ} \mathrm{C}$, at three time points ( 1 day, 3 days and 7 days after dialysis). The spectra were collected at wavelengths ranging from 205 to $260 \mathrm{~nm}$. The mean residue ellipticity was calculated from the equation:

$$
\varnothing=\frac{\mathrm{CD} \text { unit }}{10 * \text { residues } * \text { pathlength } * \mathrm{C}_{\mathrm{m}}},
$$

where $C D$ units are in mdeg and $C_{m}$ is molar concentration. Thermal denaturation was calculated from the equation:

$$
F u=\frac{\varnothing_{\mathrm{T}}-\varnothing_{\min \left(10^{\circ} \mathrm{C}\right)}}{\varnothing_{\max \left(70^{\circ} \mathrm{C}\right)}-\varnothing_{\min \left(10^{\circ} \mathrm{C}\right)}},
$$

where $\varnothing_{(\min )}$ is the mean residue ellipticity at $222 \mathrm{~nm}$ at minimum temperature, $\varnothing_{(\max )}$ is the mean residue ellipticity at $222 \mathrm{~nm}$ at maximum temperature, and $\varnothing_{\mathrm{T}}$ is the mean residue ellipticity at $222 \mathrm{~nm}$ for the tested temperature.

\section{Results and Discussion}

\subsection{Optimization of HEK-293F Cells Transfection and MPP1 Overexpression}

One of the key steps in the production of recombinant proteins in mammalian cells is the optimization of cell transfection conditions in order to obtain the best possible efficiency of overexpression while maintaining a reasonable cell viability. These parameters should be established empirically for each cell line, as no universal conditions are recognized so far. In most cases, transfection efficiency depends mainly on the DNA:PEI ratio [35,37-40]. PEI is a cationic polymer that is commonly used in transient gene expression (TGE) as a transfection reagent due to its known advantages (low costs, high transfection yields, and being easy to scale up with transfection) $[38,41]$. There are several hypotheses for how PEI introduces DNA into a cell's interior; however, all of them share the assumption that positively charged PEI interacts with negatively charged DNA to form a net-positively charged complex. These complexes can then bind to negatively charged cellular surfaces, then be transported to the cytoplasm and subsequently to the nucleus. Despite the differences in hypotheses regarding the key steps in the molecular mechanisms underlying the successful transfection of cells via DNA:PEI complexes, all agree that the translocation of the DNA from the cytoplasm to the nucleus is crucial for the transfection process [35,42-44].

Apart from the DNA:PEI ratio, the medium used for the complexation is equally important, as some components present in cell media may interfere with the delivery of the DNA:PEI polyplexes or change their properties [45,46]. Instead of testing different transfection media, this obstacle can be easily overcome with the use of $150 \mathrm{mM}$ of $\mathrm{NaCl}$. The role in the formation and stabilization of the DNA:PEI polyplexes is mostly due to the effect $\mathrm{Na}^{+}$and $\mathrm{Cl}^{-}$ions have on electrostatic interactions that stabilize polyplexes $[47,48]$. The latter formed in $\mathrm{NaCl}$ were found to be bigger and more stable than those formed in other conditions, which positively affected the transfection efficiency [47-50].

Another factor that can affect the transfection and overexpression process is the temperature during the cell culture. The mild hypothermic conditions are beneficial for recombinant protein overexpression due to cell cycle arrest and the switching of the cell towards protein synthesis; however, they may not be optimal for the transfection step [36]. Thus, in the optimization process, we focused on three crucial parameters: (1) time, (2) temperature of the transfection and (3) the DNA:PEI weight ratio. To monitor the influence of the above mentioned parameters on the expression of the mEGFP-MPP1 protein in HEK-293F cells, a fluorescent mEGFP-MPP1 construct was used, which enabled the analysis using flow cytometry. For this purpose, cells were transfected using six different DNA:PEI weight ratios $(1: 2 ; 1: 3 ; 1: 4 ; 1: 5 ; 1: 6 ; 1: 8)$, and the transfection was carried out for $5 \mathrm{~h}$ at $37^{\circ} \mathrm{C}$ or $17 \mathrm{~h}$ at the reduced temperature of $31^{\circ} \mathrm{C}$. Post transfection, cells were either recovered for $17 \mathrm{~h}$ at $37^{\circ} \mathrm{C}$ and then cultured at a reduced temperature of 
$31^{\circ} \mathrm{C}\left(5 \mathrm{~h} / 37^{\circ} \mathrm{C}\right)$, or they were kept at $31^{\circ} \mathrm{C}\left(17 \mathrm{~h} / 31^{\circ} \mathrm{C}\right)$. The level of mEGFP-MPP1 overexpression, cell density and viability were monitored after 24,48 and $72 \mathrm{~h}$ (Figure 1).

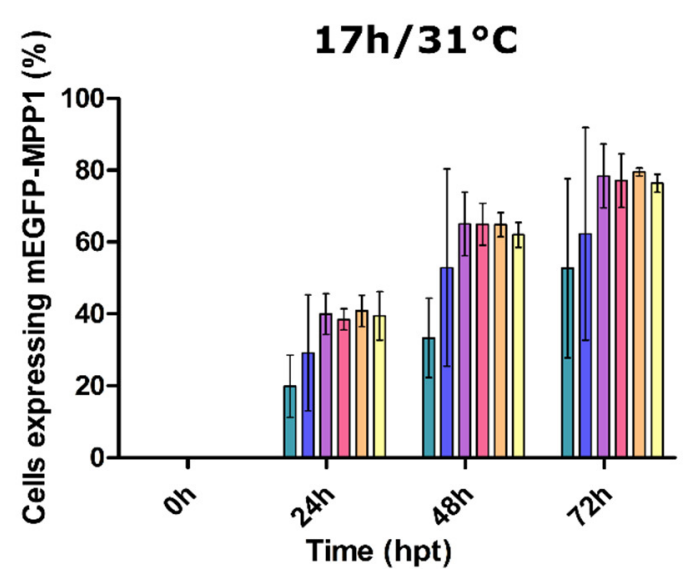

(a)

$17 \mathrm{~h} / 31^{\circ} \mathrm{C}$

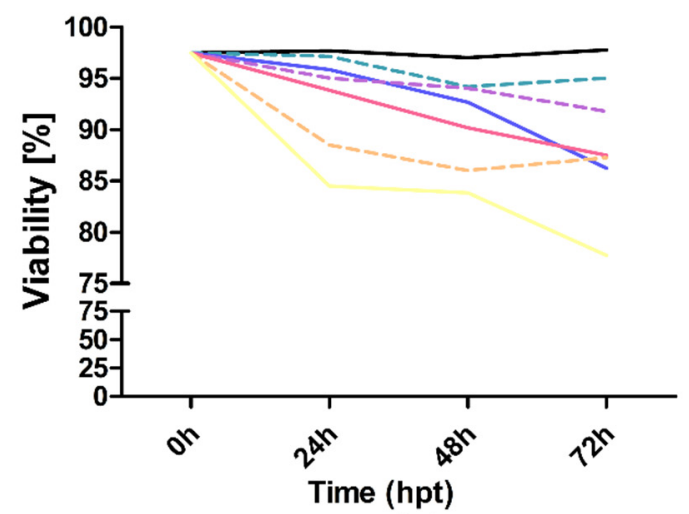

(c)

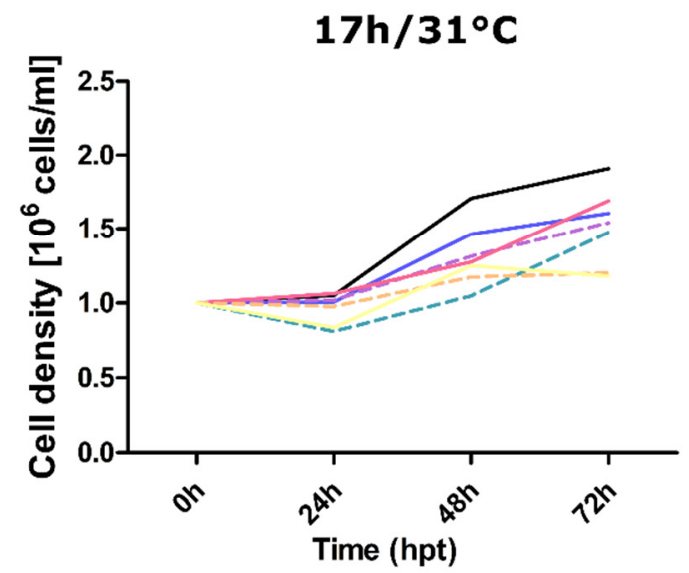

(e)

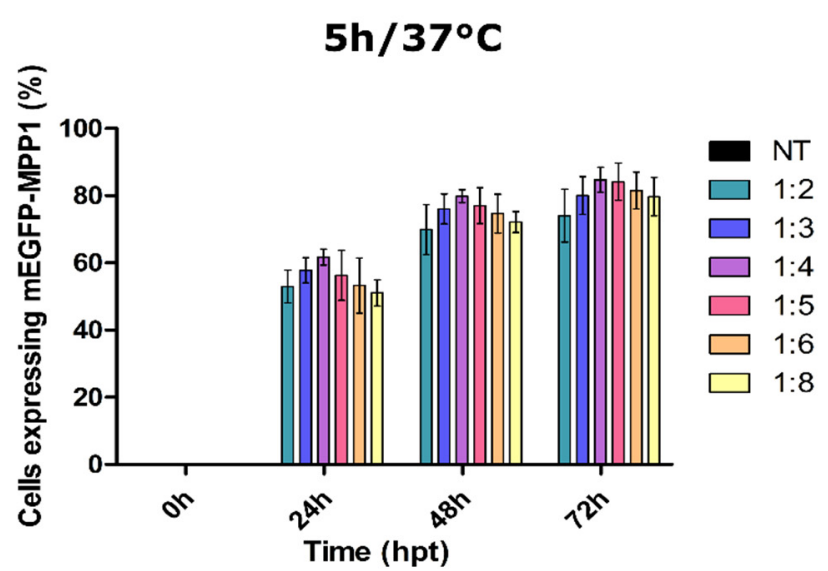

(b)

$5 \mathrm{~h} / 37^{\circ} \mathrm{C}$
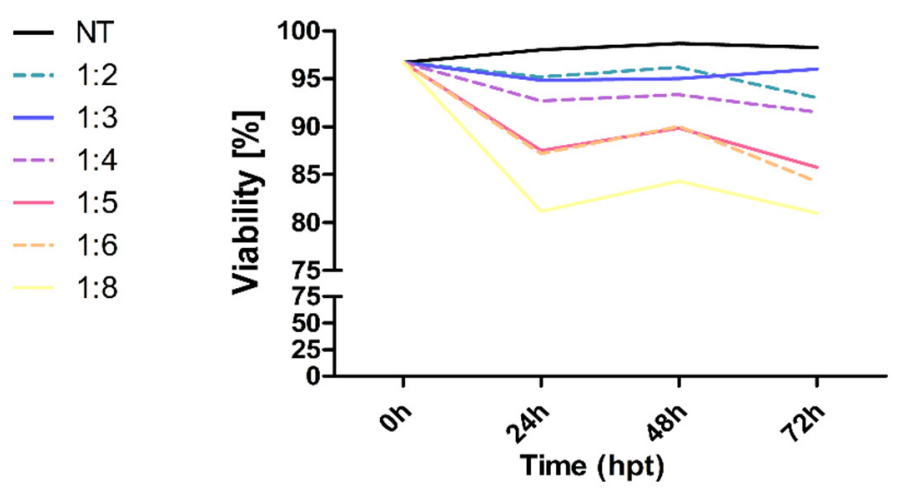

(d)

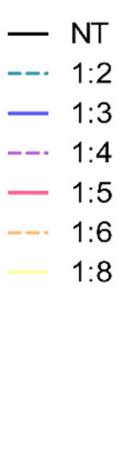

$5 \mathrm{~h} / 37^{\circ} \mathrm{C}$
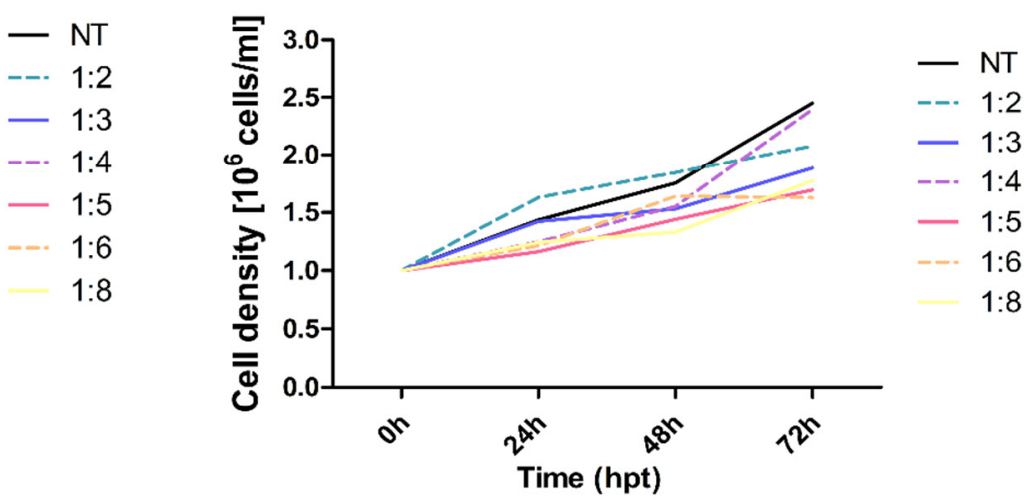

(f)

Figure 1. The effect of time, temperature, and DNA/PEI ratio on mEGFP-MPP1 overexpression and HEK-293F cell viability and density. Flow cytometry analysis of the level of mEGFP-MPP1 overexpression after (a) $17 \mathrm{~h}$ transfection at $31^{\circ} \mathrm{C}$ or (b) $5 \mathrm{~h}$ transfection at $37^{\circ} \mathrm{C}$ using different DNA:PEI ratios. Error bars represent SD. Trypan blue-based analysis of the viability of cells transfected for (c) $17 \mathrm{~h}$ at $31^{\circ} \mathrm{C}$ or (d) $5 \mathrm{~h}$ at $37^{\circ} \mathrm{C}$ with different DNA:PEI ratios. The density of cells transfected for (e) $17 \mathrm{~h}$ at $31^{\circ} \mathrm{C}$ or (f) $5 \mathrm{~h}$ at $37^{\circ} \mathrm{C}$ with different DNA:PEI ratios. NT-non-transfected cells/ control; $\mathrm{hpt}$-hours post-transfection. The procedure was performed in triplicate. 
Twenty-four hours post-transfection ( $24 \mathrm{hpt}$ ), we observed a nearly two-fold increase in mEGFP-MPP1 overexpression in cells transfected for $5 \mathrm{~h}$ at $37^{\circ} \mathrm{C}$ compared to those transfected for $17 \mathrm{~h}$ at $31^{\circ} \mathrm{C}$ (Figure 1a,b). On the last day of the overexpression (72 hpt), the total amount of overexpressed mEGFP-MPP1 was comparable in both cases (Figure 1a,b). The highest transfection levels were obtained for cells transfected for $5 \mathrm{~h}$ with 1:4 and 1:5 DNA:PEI ratios ( $84.73 \%$ and $84.14 \%$, respectively). We observed that the cell viability decreased with a decrease in the DNA:PEI ratio. Still, cells treated with 1:2-1:5 DNA:PEI presented relatively high viability (Figure 1c,d). Cells subjected to mild hypothermic conditions from the beginning showed reduced proliferation. However, the combination of lower temperature with a prolonged exposition to DNA-PEI complex did not improve the overall expression efficiency. For the cells transfected at $37^{\circ} \mathrm{C}$ and then transferred to the $31^{\circ} \mathrm{C} 24 \mathrm{hpt}$, the slowest growth combined with acceptable viability is seen for the ratio 1:5 (Figure 1e). Taking into account the results discussed above and the fact that the target plasmid was slightly larger (Figure S1), we decided that a $5 \mathrm{~h}$ transfection at $37^{\circ} \mathrm{C}$ and a 1:5 DNA:PEI ratio was the most suitable for our further experiments.

\subsection{Protein Purification}

The MPP1 protein was purified in native conditions using affinity chromatography towards a TAP-tag as described in the materials and methods. The level of the overexpressed protein was monitored through the increasing signal from the samples collected during the overexpression in HEK-293F cells (Figure 2a, 0-72 h). As MPP1 is a peripheral protein, the original idea was to fractionate the cell lysate into "cytosolic" and "membrane" fractions; however, as the protein level of MPP1 in these fractions was comparable (Figure S2), we decided to omit the fractionation step and instead purify the recombinant protein from whole cell lysate-see Figure S2. Both approaches exhibited a comparable purification efficiency. Overall, the optimized conditions of transfection and expression allowed the high-yield purification of recombinant MPP1 from HEK-293F cells. From a $2 \mathrm{~L}$ cell culture, we were able to obtain a total of $5 \mathrm{mg}$ of recombinant protein.

Oh $24 h \quad 48 h \quad 72 h \quad S_{1} P_{1}$ MPP1

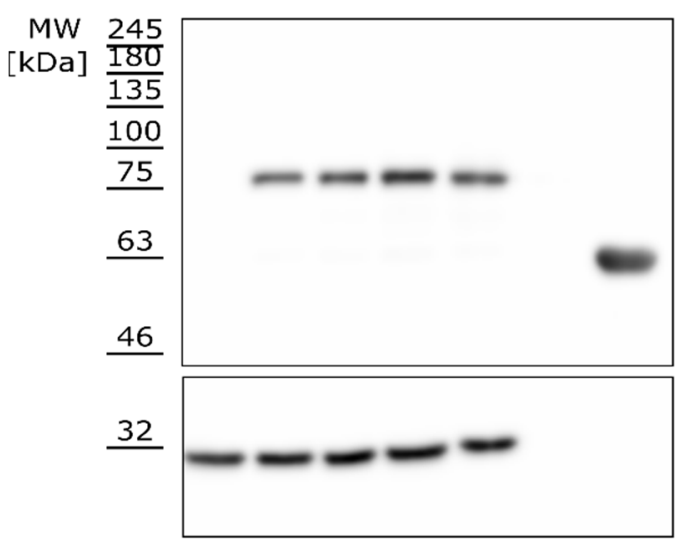

(a)

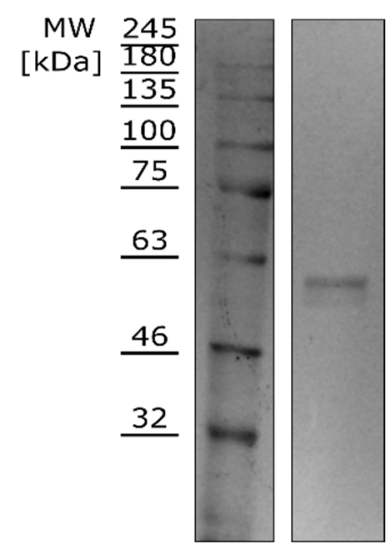

(b)

Figure 2. Expression and purification of MPP1 protein from HEK-293F cells. Western blot analysis of (a) crude cell lysates collected through transfection ( $0 \mathrm{~h}-72 \mathrm{~h})$, samples collected after centrifugation $(\mathrm{S} 1, \mathrm{P} 1)$ and purified recombinant protein $(2 \mu \mathrm{g})$. The upper membrane was incubated with Anti-Histag antibodies to detect overexpressed MPP1 and the lower membrane with Anti-GAPDH antibodies; (b) Coomassie blue staining of the SDS-PAGE gel with purified recombinant MPP1. The lower mass of purified recombinant MPP1 is a result of TAP-tag cleavage during the purification (for details, see Figure S1b). 


\subsection{Secondary Structure}

In the next step, the secondary structure of the purified MPP1 protein was analyzed using $\mathrm{CD}$, including the analysis of protein thermal stability at selected storage-time points. The obtained CD spectra show a clear minimum at $208 \mathrm{~nm}$ and another around $220 \mathrm{~nm}$, which suggests a mix of the alpha-helical and beta structure of the protein (Figure 3a). These results are compatible with our theoretical model [51], AlphaFold predictions [52], CD spectra-based structure analysis with the BeStSel algorithm [53], and the CD results obtained for the protein purified in the bacterial system [21]. The values calculated from the model indicate that these two secondary-structure types account for approximately $40 \%$ of the protein structure. Additionally, the comparative analysis of the collected spectra indicates that the protein stored at $4{ }^{\circ} \mathrm{C}$ remains stable even one week after thawing (Figure 3). The data from thermal melting curve analysis of the MPP1 protein for each sample were fitted to the Boltzmann sigmoid curve (GraphPad Prism, GraphPad Software Inc., San Diego, CA, USA) and the melting temperature was calculated to be approximately $39^{\circ} \mathrm{C}$ (Figure $3 \mathrm{~b}$ ).

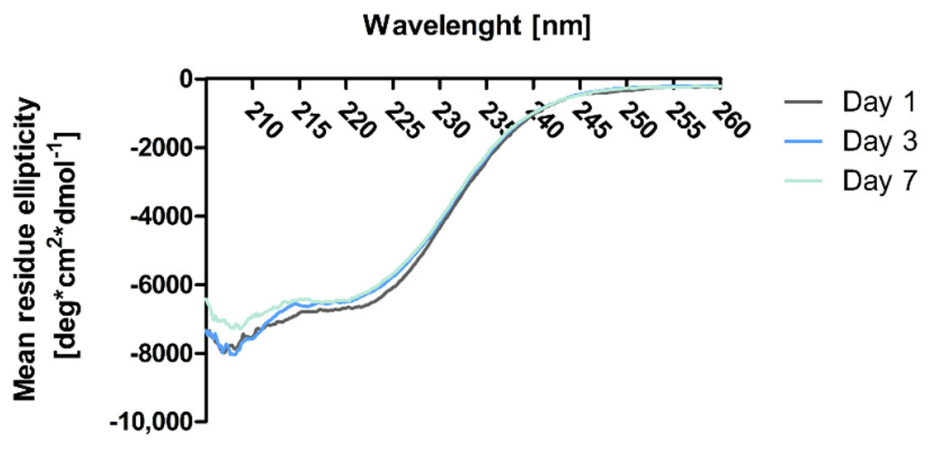

(a)

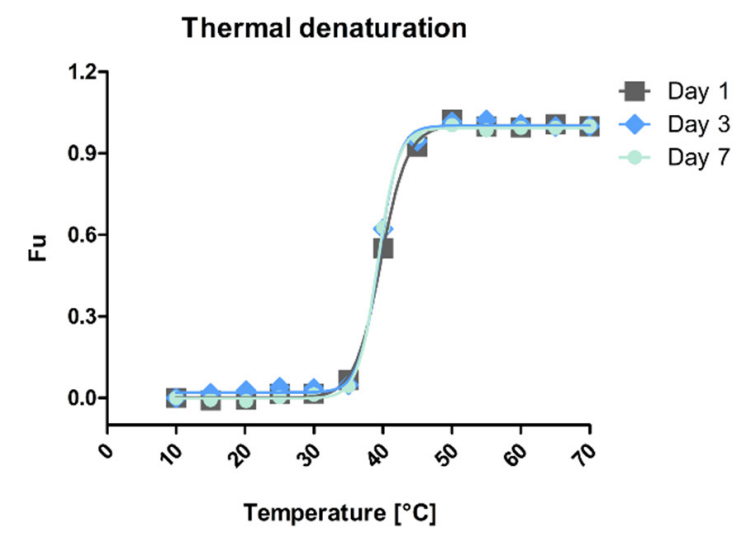

(b)

Figure 3. Characterization of the purified recombinant MPP1 protein using circular dichroism spectroscopy. (a) CD spectra of MPP1 protein 1, 3, and 7 days after dialysis recorded at $20^{\circ} \mathrm{C}$. (b) Thermal denaturation of MPP1 protein reflected via changes in ellipticity at $222 \mathrm{~nm}$. The MPP1 was stored at $4{ }^{\circ} \mathrm{C}$. Fu-fraction unfolded.

\subsection{Analysis of S-Palmitoylation}

The main goal of this study was to purify naturally palmitoylated recombinant MPP1 overexpressed in HEK-293F cells, which largely reflects the endogenous protein found in the PM of eukaryotic cells. The presence of this modification in the overexpressed lysates and purified MPP protein fraction was checked by the Acyl-RAC method [54]. Briefly, the method consists of three main steps: a blocking step, cleavage step, and capture step. The procedure started with the blocking of free thiol groups. After that, the remaining palmitate groups were removed with a thioester cleavage reagent (cleaved fraction, $\mathrm{cF}$ ) or left untreated with a preservative (preserved fraction, $\mathrm{pF}$ ). The proteins, with newly released thiol groups, were incubated with the capture resin. In the final step, the captured proteins (which represent the palmitoylated species) were eluted and then analyzed via a Western blot.

The results obtained with the Acyl-RAC method confirmed that by using our optimized protocol we were able to overexpress and purify naturally palmitoylated recombinant MPP1 from HEK-293F cells (Figure 4). As can be observed, the entire pool of overexpressed MPP1 does not undergo palmitoylation; however, this may be due to the dynamic palmitoylation/depalmitoylation cycles that were previously shown for several endogenous palmitoylated proteins in the HEK-293T cells [55]. Such an issue might be 
further overcome by the use of APTs inhibitors-e.g., Palmostatin B-during overexpression and/or purification [56,57]. Another possibility to increase the palmitoylation level of recombinant proteins is the co-expression of recombinant protein with specific PAT/PATs enzyme(s) [57-59]. However, in the case of MPP1, such a task would be difficult to accomplish, as currently it is unknown which DHHC enzyme palmitoylates the MPP1 protein or whether any specificity of DHHCs towards MPP1 exists. In mammals, the family of PATs consists of 23 members and often more than one enzyme modifies a given protein; therefore, finding appropriate DHHC is rather challenging [59-61].

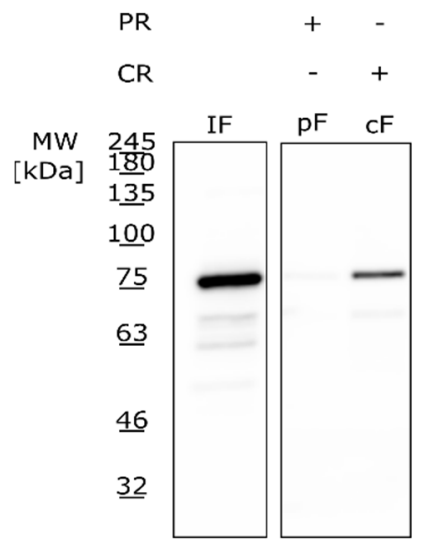

(a)

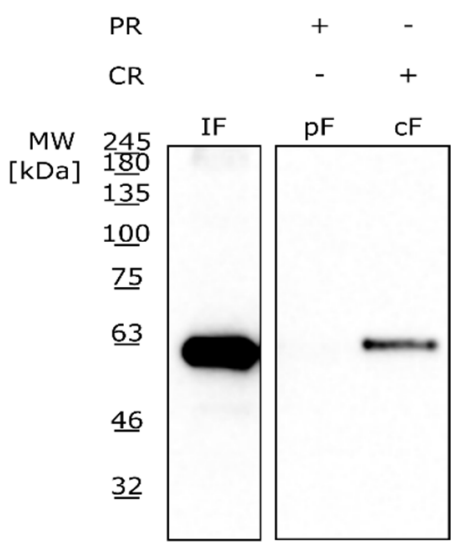

(b)

Figure 4. Identification of palmitoylation of overexpressed recombinant MPP1 protein by the AcylRAC method. Identification of palmitoylation of (a) overexpressed MPP1 protein in HEK-293F lysates and (b) recombinant MPP1 purified from HEK-293F cells. Both membranes were incubated with AntiHis-tag antibodies to detect recombinant MPP1. IF-input fraction (sample taken before the cleavage step); $\mathrm{pF}$ - preserved fraction; $\mathrm{cF}$-cleaved fraction; $\mathrm{PR}$ - preservative reagent; $\mathrm{CR}$ —cleavage reagent.

\section{Conclusions}

This study aimed to find the optimal transfection parameters for the maximized overexpression yield of naturally palmitoylated recombinant MPP1 in HEK-293F cells. Using our optimized protocol, we were able to obtain a good purification efficiency ( $5 \mathrm{mg} /$ per $2 \mathrm{~L}$ of cell culture) of the recombinant MPP1 protein which, as shown by the Acyl-RAC method, is palmitoylated, well folded, and stable in solution. The presented approach may be considered as a showcase paving the way to further optimize the overexpression levels, purification yields, and palmitoylation levels of various peripheral membrane proteins. We believe that the protocol described above may be of great value for other researchers who intend to investigate the direct impact of palmitoylated proteins in vitro-e.g., in combination with membrane model systems in bottom-up reconstitution approaches.

Supplementary Materials: The following are available online at https:/ /www.mdpi.com/article/10 .3390/membranes11090715/s1: Figure S1: Plasmid maps and recombinant protein schemes; Table S1: Primers used for cloning and mutagenesis; Figure S2: Expression and fractionation of MPP1 protein from HEK-293F cells.

Author Contributions: A.C. (Agnieszka Chytła) and A.B. designed the experiments. A.C. (Agnieszka Chytła) performed all the experiments, except the Acyl-RAC experiments with recombinant protein performed by W.G.-N., A.C. (Agnieszka Chytła), A.C. (Aleksander Czogalla), and A.B. analyzed the results. A.C. (Agnieszka Chytła) and W.G.-N. wrote the original draft. A.B., A.C. (Aleksander Czogalla) and A.F.S. reviewed and edited the manuscript. A.B. and A.C. (Aleksander Czogalla) conceptualized and supervised the project. A.C. (Aleksander Czogalla) was responsible for funding acquisition. All authors have read and agreed to the published version of the manuscript.

Funding: This work was supported by the National Science Centre, Poland, 2016/21/B/NZ1/02821. 
Acknowledgments: We thank Michal Grzybek and Beate Brankatschk for their initial assistance and support. We also thank Piotr Hinc for his help with CD measurements.

Conflicts of Interest: The authors declare no known competing financial interests or personal relationships which have influenced the work reported in this article.

\section{References}

1. Funke, L.; Dakoji, S.; Bredt, D.S. Membrane-Associated Guanylate Kinases Regulate Adhesion and Plasticity At Cell Junctions. Annu. Rev. Biochem. 2005, 74, 219-245. [CrossRef]

2. Oliva, C.; Escobedo, P.; Astorga, C.; Molina, C.; Sierralta, J. Role of the maguk protein family in synapse formation and function. Dev. Neurobiol. 2012, 72, 57-72. [CrossRef]

3. Zhu, J.; Shang, Y.; Zhang, M. Mechanistic basis of MAGUK-organized complexes in synaptic development and signalling. Nat. Rev. Neurosci. 2016, 17, 209-223. [CrossRef] [PubMed]

4. Chytła, A.; Gajdzik-Nowak, W.; Olszewska, P.; Biernatowska, A.; Sikorski, A.F.; Czogalla, A. Not Just Another Scaffolding Protein Family: The Multifaceted MPPs. Molecules 2020, 25, 4954. [CrossRef] [PubMed]

5. Seo, P.S.; Jeong, J.J.; Zeng, L.; Takoudis, C.G.; Quinn, B.J.; Khan, A.A.; Hanada, T.; Chishti, A.H. Alternatively spliced exon 5 of the FERM domain of protein 4.1R encodes a novel binding site for erythrocyte $\mathrm{p} 55$ and is critical for membrane targeting in epithelial cells. Biochim. Biophys. Acta Mol. Cell Res. 2009, 1793, 281-289. [CrossRef] [PubMed]

6. Ruff, P.; Speicher, D.W.; Husain-Chishti, A. Molecular identification of a major palmitoylated erythrocyte membrane protein containing the src homology 3 motif. Proc. Natl. Acad. Sci. USA 1991, 88, 6595-6599. [CrossRef]

7. Alloisio, N.; Dalla Venezia, N.; Rana, A.; Andrabi, K.; Texier, P.; Gilsanz, F.; Cartron, J.P.; Delaunay, J.; Chishti, A.H. Evidence that red blood cell protein p55 may participate in the skeleton- membrane linkage that involves protein 4.1 and glycophorin C. Blood 1993, 82, 1323-1327. [CrossRef]

8. Marfatia, S.M.; Lue, R.A.; Branton, D.; Chishti, A.H. In vitro binding studies suggest a membrane-associated complex between erythroid p55, protein 4.1, and glycophorin C. J. Biol. Chem. 1994, 269, 8631-8634. [CrossRef]

9. Biernatowska, A.; Podkalicka, J.; Majkowski, M.; Hryniewicz-Jankowska, A.; Augoff, K.; Kozak, K.; Korzeniewski, J.; Sikorski, A.F. The role of MPP1/p55 and its palmitoylation in resting state raft organization in HEL cells. Biochim. Biophys. Acta Mol. Cell Res. 2013, 1833, 1876-1884. [CrossRef]

10. Biernatowska, A.; Augoff, K.; Podkalicka, J.; Tabaczar, S.; Gajdzik-Nowak, W.; Czogalla, A.; Sikorski, A.F. MPP1 directly interacts with flotillins in erythrocyte membrane-Possible mechanism of raft domain formation. Biochim. Biophys. Acta Biomembr. 2017, 1859, 2203-2212. [CrossRef]

11. Podkalicka, J.; Biernatowska, A.; Olszewska, P.; Tabaczar, S.; Sikorski, A.F. The microdomain-organizing protein MPP1 is required for insulinstimulated activation of H-Ras. Oncotarget 2018, 9, 18410-18421. [CrossRef]

12. Trybus, M.; Niemiec, L.; Biernatowska, A.; Hryniewicz-Jankowska, A.; Sikorski, A.F. MPP1-based mechanism of resting state raft organization in the plasma membrane. Is it a general or specialized mechanism in erythroid cells? Folia Histochem. Cytobiol. 2019, 57, 43-55. [CrossRef]

13. Podkalicka, J.; Biernatowska, A.; Majkowski, M.; Grzybek, M.; Sikorski, A.F. MPP1 as a factor regulating phase separation in giant plasma membrane-derived vesicles. Biophys. J. 2015, 108, 2201-2211. [CrossRef] [PubMed]

14. Lingwood, D.; Simons, K. Detergent resistance as a tool in membrane research. Nat. Protoc. 2007, 2, 2159-2165. [CrossRef] [PubMed]

15. Sezgin, E.; Levental, I.; Mayor, S.; Eggeling, C. The mystery of membrane organization: Composition, regulation and physiological relevance of lipid rafts. Nat. Rev. Mol. Cell Biol. 2017, 18, 361-374. [CrossRef] [PubMed]

16. Sikorski, A.F.; Podkalicka, J.; Jones, W.; Biernatowska, A. Membrane Rafts in the Erythrocyte Membrane: A Novel Role of MPP1p55. In Biochemical Roles of Eukaryotic Cell Surface Macromolecules, Advances in Experimental Medicine and Biology; Springer: Cham, Switzerland, 2015; Volume 842, pp. 61-78, ISBN 978-3-319-11279-4.

17. Banning, A.; Tomasovic, A.; Tikkanen, R. Functional Aspects of Membrane Association of Reggie/Flotillin Proteins. Curr. Protein Pept. Sci. 2011, 12, 725-735. [CrossRef] [PubMed]

18. Guillaume, E.; Comunale, F.; Do Khoa, N.; Planchon, D.; Bodin, S.; Gauthier-Rouvière, C. Flotillin microdomains stabilize cadherins at cell-cell junctions. J. Cell Sci. 2013, 126, 5284-5292. [CrossRef]

19. Kurrle, N.; Völlner, F.; Eming, R.; Hertl, M.; Banning, A.; Tikkanen, R. Flotillins directly interact with $\gamma$-catenin and regulate epithelial cell-cell adhesion. PLoS ONE 2013, 8. [CrossRef]

20. Kwiatkowska, K.; Matveichuk, O.V.; Fronk, J.; Ciesielska, A. Flotillins: At the intersection of protein S-palmitoylation and lipid-mediated signaling. Int. J. Mol. Sci. 2020, 21, 2283. [CrossRef] [PubMed]

21. Biernatowska, A.; Olszewska, P.; Grzymajło, K.; Drabik, D.; Kraszewski, S.; Sikorski, A.F.; Czogalla, A. Molecular characterization of direct interactions between MPP1 and flotillins. Sci. Rep. 2021, 11, 14751. [CrossRef]

22. Hancock, J.F. Lipid rafts: Contentious only from simplistic standpoints. Nat. Rev. Mol. Cell Biol. 2006, 7, 456-462. [CrossRef]

23. Levental, I.; Levental, K.R.; Heberle, F.A. Lipid Rafts: Controversies Resolved, Mysteries Remain. Trends Cell Biol. 2020, 30, 341-353. [CrossRef]

24. Zhang, M.M.; Hang, H.C. Protein S-palmitoylation in cellular differentiation. Biochem. Soc. Trans. 2017, 45, 275-285. [CrossRef] [PubMed] 
25. El-Husseini, A.E.; Craven, S.E.; Chetkovich, D.M.; Firestein, B.L.; Schnell, E.; Aoki, C.; Bredt, D.S. Dual palmitoylation of PSD-95 mediates its vesiculotubular sorting, postsynaptic targeting, and ion channel clustering. J. Cell Biol. 2000, 148, 159-171. [CrossRef] [PubMed]

26. Schnell, E.; Sizemore, M.; Karimzadegan, S.; Chen, L.; Bredt, D.S.; Nicoll, R.A. Direct interactions between PSD-95 and stargazin control synaptic AMPA receptor number. Proc. Natl. Acad. Sci. USA 2002, 99, 13902-13907. [CrossRef] [PubMed]

27. Sohn, H.; Park, M. Palmitoylation-mediated synaptic regulation of AMPA receptor trafficking and function. Arch. Pharm. Res. 2019, 42, 426-435. [CrossRef] [PubMed]

28. Tulodziecka, K.; Diaz-Rohrer, B.B.; Farley, M.M.; Chan, R.B.; Di Paolo, G.; Levental, K.R.; Waxham, M.N.; Levental, I. Remodeling of the postsynaptic plasma membrane during neural development. Mol. Biol. Cell 2016, 27, 3480-3489. [CrossRef] [PubMed]

29. Marfatia, S.M.; Lue, R.A.; Branton, D.; Chishti, A.H. Identification of the protein 4.1 binding interface on glycophorin C and p55, a homologue of the Drosophila discs-large tumor suppressor protein. J. Biol. Chem. 1995, 270, 715-719. [CrossRef] [PubMed]

30. Gray, D. Overview of Protein Expression by Mammalian Cells. Curr. Protoc. Protein Sci. 1997, 10, 1-18. [CrossRef] [PubMed]

31. Hunter, M.; Yuan, P.; Vavilala, D.; Fox, M. Optimization of Protein Expression in Mammalian Cells. Curr. Protoc. Protein Sci. 2019, 95, 1-28. [CrossRef]

32. Hossler, P.; Khattak, S.F.; Li, Z.J. Optimal and consistent protein glycosylation in mammalian cell culture. Glycobiology 2009, 19, 936-949. [CrossRef] [PubMed]

33. Silva, F.D.; Oliveira, J.E.; Freire, R.P.; Suzuki, M.F.; Soares, C.R.; Bartolini, P. Expression of glycosylated human prolactin in HEK293 cells and related N-glycan composition analysis. AMB Express 2019, 9. [CrossRef]

34. Kozak, S.; Bloch, Y.; De Munck, S.; Mikula, A.; Bento, I.; Savvides, S.N.; Meijers, R. Homogeneously N-glycosylated proteins derived from the GlycoDelete HEK293 cell line enable diffraction-quality crystallogenesis. Acta Crystallogr. Sect. D Struct. Biol. 2020, 76, 1244-1255. [CrossRef]

35. Gutiérrez-Granados, S.; Cervera, L.; Kamen, A.A.; Gòdia, F. Advancements in mammalian cell transient gene expression (TGE) technology for accelerated production of biologics. Crit. Rev. Biotechnol. 2018, 38, 918-940. [CrossRef] [PubMed]

36. Sunley, K.; Butler, M. Strategies for the enhancement of recombinant protein production from mammalian cells by growth arrest. Biotechnol. Adv. 2010, 28, 385-394. [CrossRef]

37. Fuenmayor, J.; Cervera, L.; Gutiérrez-Granados, S.; Gòdia, F. Transient gene expression optimization and expression vector comparison to improve HIV-1 VLP production in HEK293 cell lines. Appl. Microbiol. Biotechnol. 2018, 102, 165-174. [CrossRef]

38. Delafosse, L.; Xu, P.; Durocher, Y. Comparative study of polyethylenimines for transient gene expression in mammalian HEK293 and CHO cells. J. Biotechnol. 2016, 227, 103-111. [CrossRef]

39. Rajendra, Y.; Kiseljak, D.; Baldi, L.; Wurm, F.M.; Hacker, D.L. Transcriptional and post-transcriptional limitations of high-yielding, PEI-mediated transient transfection with CHO and HEK-293E cells. Biotechnol. Prog. 2015, 31, 541-549. [CrossRef] [PubMed]

40. Xie, Q.; Xinyong, G.; Xianjin, C.; Yayu, W. PEI/DNA formation affects transient gene expression in suspension Chinese hamster ovary cells via a one-step transfection process. Cytotechnology 2013, 65, 263-271. [CrossRef]

41. Lai, W.F. In vivo nucleic acid delivery with PEI and its derivatives: Current status and perspectives. Expert Rev. Med. Devices 2011, 8, 173-185. [CrossRef]

42. Won, Y.-Y.; Sharma, R.; Konieczny, S.F. Missing pieces in understanding the intracellular trafficking of polycation/DNA complexes. J. Control. Release 2009, 139, 88-93. [CrossRef] [PubMed]

43. Suh, J.; Wirtz, D.; Hanes, J. Efficient active transport of gene nanocarriers to the cell nucleus. Proc. Natl. Acad. Sci. USA 2003, 100, 3878-3882. [CrossRef]

44. Brunner, S.; Sauer, T.; Carotta, S.; Cotten, M.; Saltik, M.; Wagner, E. Cell cycle dependence of gene transfer by lipoplex polyplex and recombinant adenovirus. Gene Ther. 2000, 7, 401-407. [CrossRef] [PubMed]

45. Cervera, L.; Gutiérrez-Granados, S.; Martínez, M.; Blanco, J.; Gòdia, F.; Segura, M.M. Generation of HIV-1 Gag VLPs by transient transfection of HEK 293 suspension cell cultures using an optimized animal-derived component free medium. J. Biotechnol. 2013, 166, 152-165. [CrossRef]

46. Tom, R.; Bisson, L.; Durocher, Y. Transfection of HEK293-EBNA1 cells in suspension with linear PEI for production of recombinant proteins. Cold Spring Harb. Protoc. 2008, 3, 1-5. [CrossRef]

47. Sang, Y.; Xie, K.; Mu, Y.; Lei, Y.; Zhang, B.; Xiong, S.; Chen, Y.; Qi, N. Salt ions and related parameters affect PEI-DNA particle size and transfection efficiency in Chinese hamster ovary cells. Cytotechnology 2015, 67, 67-74. [CrossRef] [PubMed]

48. González-Domínguez, I.; Grimaldi, N.; Cervera, L.; Ventosa, N.; Gòdia, F. Impact of physicochemical properties of DNA/PEI complexes on transient transfection of mammalian cells. New Biotechnol. 2019, 49, 88-97. [CrossRef]

49. Daramola, O.; Stevenson, J.; Dean, G.; Hatton, D.; Pettman, G.; Holmes, W.; Field, R. A high-yielding CHO transient system: Coexpression of genes encoding EBNA-1 and GS enhances transient protein expression. Biotechnol. Prog. 2014, 30, $132-141$. [CrossRef] [PubMed]

50. Bono, N.; Ponti, F.; Mantovani, D.; Candiani, G. Non-viral in vitro gene delivery: It is now time to set the bar! Pharmaceutics 2020, 12, 183. [CrossRef]

51. Listowski, M.A.; Leluk, J.; Kraszewski, S.; Sikorski, A.F. Cholesterol interaction with the MAGUK protein family member, MPP1, via CRAC and CRAC-like motifs: An in silico docking analysis. PLoS ONE 2015, 10, 1-15. [CrossRef] [PubMed]

52. Jumper, J.; Evans, R.; Pritzel, A.; Green, T.; Figurnov, M.; Ronneberger, O.; Tunyasuvunakool, K.; Bates, R.; Žídek, A.; Potapenko, A.; et al. Highly accurate protein structure prediction with AlphaFold. Nature 2021, 596, 583-589. [CrossRef] 
53. Micsonai, A.; Bulyáki, É.; Kardos, J. BeStSel: From Secondary Structure Analysis to Protein Fold Prediction by Circular Dichroism Spectroscopy. Methods Mol. Biol. 2021, 2199, 175-189. [CrossRef]

54. Forrester, M.T.; Hess, D.T.; Thompson, J.W.; Hultman, R.; Moseley, M.A.; Stamler, J.S.; Casey, P.J. Site-specific analysis of protein S-acylation by resin-assisted capture. J. Lipid Res. 2011, 52, 393-398. [CrossRef]

55. Martin, B.R.; Wang, C.; Adibekian, A.; Tully, S.E.; Cravatt, B.F. Global profiling of dynamic protein palmitoylation. Nat. Methods 2012, 9, 84-89. [CrossRef] [PubMed]

56. Won, S.J.; Cheung See Kit, M.; Martin, B.R. Protein depalmitoylases. Crit. Rev. Biochem. Mol. Biol. 2018, 53, 83-98. [CrossRef]

57. Gök, C.; Plain, F.; Robertson, A.D.; Howie, J.; Baillie, G.S.; Fraser, N.J.; Fuller, W. Dynamic Palmitoylation of the Sodium-Calcium Exchanger Modulates Its Structure, Affinity for Lipid-Ordered Domains, and Inhibition by XIP. Cell Rep. 2020, 31. [CrossRef] [PubMed]

58. Kokkola, T.; Kruse, C.; Roy-Pogodzik, E.M.; Pekkinen, J.; Bauch, C.; Hönck, H.H.; Hennemann, H.; Kreienkamp, H.J. Somatostatin receptor 5 is palmitoylated by the interacting ZDHHC5 palmitoyltransferase. FEBS Lett. 2011, 585, 2665-2670. [CrossRef] [PubMed]

59. Tian, L.; McClafferty, H.; Jeffries, O.; Shipston, M.J. Multiple palmitoyltransferases are required for palmitoylation-dependent regulation of large conductance calcium- and voltage-activated potassium channels. J. Biol. Chem. 2010, 285, 23954-23962. [CrossRef] [PubMed]

60. McMichael, T.M.; Zhang, L.; Chemudupati, M.; Hach, J.C.; Kenney, A.D.; Hang, H.C.; Yount, J.S. The palmitoyltransferase ZDHHC20 enhances interferon-induced transmembrane protein 3 (IFITM3) palmitoylation and antiviral activity. J. Biol. Chem. 2017, 292, 21517-21526. [CrossRef]

61. Bolland, D.E.; Moritz, A.E.; Stanislowski, D.J.; Vaughan, R.A.; Foster, J.D. Palmitoylation by Multiple DHHC Enzymes Enhances Dopamine Transporter Function and Stability. ACS Chem. Neurosci. 2019, 10, 2707-2717. [CrossRef] 